\title{
ANALISI SURGENSI PERPPU NOMOR 1 TAHUN 2107 TENTANG AKSES INFORMASI KEUANGAN UNTUK KEPENTINGAN PERPAJAKAN
}

\author{
Oleh : \\ 1) Ifat Hanifah \\ ${ }^{1)}$ Fakultas Hukum dan Sosial, Universitas Mathla'ul Anwar \\ ${ }^{1)}$ Email:gifhan.moeslim69@gmail.com
}

\begin{abstract}
ABSTRAK
Keterbukaan informasi keuangan untuk kepentingan perpajakan merupakan komitmen internasional dalam Global Forum on Transparency and Excange of Informationfor tax Purposes (Global Forum), Indonesia sebagai salah satu anggota diwajibkan memiliki regulasi doestik terkait keterbukaan akses informasi keuangan terkait perpajakan. Ketidakpatuhan terhadap komitmen dalam global forum secara signifikan akan mengguncang perekonomian nasional karena dicap dunia sebagai negara beresiko gagal (at risk). Penulisan penelitian ini mengunakan studi kepustakaan atau litelatur.Data-data yang diperoleh dalam penelitian ini bersumber dari pustaka atau dokumen. Hasil penelitian menunjukan komitmen Indonesia tebukti dengan diterbitkannya Perppu Nomor 1 Tahun 2017 Tentang Akses Informasi Keuangan Untuk Kepentingan Perpajakan, yang sekaligus sebagai upaya protektif terhadap masuknya dana illegal ke Indonesia. Disamping membeikan citra dan kepercayaan terhadap investor dalam menanamkan modalnya di Indonesia.
\end{abstract}

Kata kunci: Perpu, Akses Informasi, Perpajakan. 


\section{PENDAHULUAN}

Perppu atau Peraturan Pemerintah Pengganti Undang-undang pada dasarnya merupakan hak Presiden dalam memecahkan persoalan dalam kaitan kodisi yang urgent atau mendesak. Sesuai dengan bunyi Pasal 22 UUD 1945 ayat(1) Dalam hal ihwal kegentingan yang memaksa, Presiden berhak menetapkan peraturan pemerintah sebagai pengganti undang-undang. 2)Peraturan pemerintah itu harus mendapat persetujuan Dewan Perwakilan Rakyat dalam persidangan yang berikut. (3) Jika tidak mendapat persetujuan, maka peraturan pemerintah itu harus dicabut. Pada era saat ini terjadi krisis keuangan global dan Perpajakan, dimulai dari krisis global tahun 2008, sehingga terjadi perlambatan dan ketidak pastian ekonomi dunia. Akibat itu diperlukan pendanaan untuk membiayai penyehatan sektor keuangan dan stimulis ekonomi untuk bangkit dari krisis, terutama dari pajak. Dimana dalam basis pajak banyak pengelakan pajak, yang memanfaatkan keterbatasan akses informasi keuangan. Berdasarkan sumber yang penulis dapati modus pengelakan pajak yaitu dengan menggeser profit dan menyimpan uang dari hasil kegiatan tersebut di negara-negara suaka pajak (tax havens) atau offshore Financial Center. Sebelumya Indonesia pada tahun 2015 sudah ikut menandatangani Multilateral Competent Authotity Agreement yang mencantumkan komitmen Indonesia untuk memulai Automatic Exchange Of Information (AEOI) atau Pertukaran Informasi Otomatis pada bulan September 2018. Bersama 100 negara lain indonesia berkomitmen untuk melakukan keterbukaan informasi. Berdasarkan data yang penulis peroleh 50 negara telah mulai bertukar informasi keuangan pada tahun 2017 dan 50 akan memulai ditahun 2018. Ihwal di atas memiliki korelasi yang erat dengan berlangsungnya pembangunan Nasional.Bahwasanya dalam rangka melaksanakan pembangunan nasional yang esensinya mensejahterakan dan memakmurkan seluruh rakyat Indonesia secara merata dan berkeadilan.Hal tersebut selaras dengan amanat Pembukaan Undang-Undang Dasar Negara Republik Indonesia 1945, bahwa "dibutuhkan pendanaan yang bersumber dari penerimaan negara terutama yang berasal dari pajak". Lebih lanjut telah diatur dalam UUD 1945 Pasal 23A yang menyatakan bahwa "pajak dan pungutan lainnya yang bersifat memaksa untuk 
keperluan negara diatur dangan undang-undang. Berdasarkan uraian di atas mengartikan bahwa terdapat urgensi di terbitkannya Peraturan Pemerintah penganti Undang-Undang bagi otoritas perpajakan bagi otoritas perpajakan guna menerima dan memperoleh data/informasi keuangan bagi kepentingan perpajakan dalam pembentukan system basis data yang akurat dan kuat (Hidayat, 2017).

\section{KAJIAN PUSTAKA}

Peraturan Perundang-undangan di Indonesia tdiatur dalam Undang-Undang Nomor 12 Tahun 2011 mengenai Pembentukan Peraturan perundang-undangan.Bagir Manan menyatakan bahwa "peraturan perundang-undangan adalah keputusan tertulis negara atau pemerintah yang berisi petunjuk atau pola tingkah laku yang bersifat dan mengikat secara umum". Lebih lanjut menurut Maria Farida (2006) terdapat dua pengertian istilah perundang-undangan yang berbeda, diantaranya:

1. Perundang-undangan merupakan suatu proses pembantukan peraturan-peraturan negara, baik pada tartan pusat maupun daerah.

2. Perundang-undangan adalah segala peraturan negara, yang merupakan hasil pembentukan peraturan-peraturan baik tingkat pusat maupun tingkat daerah.

Kecepatan dan tersedianya akses informasi merupakan salah satu urgensi dari tujuan pembentukan Automatic Exchange Of Information (AEOI). Akses informasi kata informasi sendiri berdasarkan Oxford English Dictionary, memiliki pengertian, 1) The Action of informing.The action of telling or fact of being being told of something. 2) That which one is apprised or told, intelegence, news (Donal, 2007:42). Selaras dengan definisi sebelumnya Akses informasi menurut Kementerian Informasi dan Komunikasi adalah "kemudahan yang diberikan kepada seseorang atau masyarakat untuk memperoleh informasi publik yang diberikan".

\section{METODE}

Penulisan penelitian ini mengunakan studi kepustakaan atau litelatur.Data-data yang 
diperoleh dalam penelitian ini bersumber dari pustaka atau dokumen. Menurut Zed (2014), pada riset pustaka penelurusan kepustakaan tidak hanya untuk langkah awal menyiapkan kerangka penelitian akan tetapi sekaligus memanfaatkan sumber-sumber perpustakaan untuk memperoleh data peneitian.

\section{PEMBAHASAN}

\section{A. Komitmen Indonesia}

Perppu dibuat oleh Presiden dalam menjaga kondisi kenegaraan agar tetap aman dan kondusif, seperti yang akan dibahas mengenai terbitynya Perppu No 1 Tahun 2017 tentang Akses Informasi Keuangan Untuk Kepentingan Perpajakan. Bertalian dengan hal kegentingan yang bersifat urgen, pasalnyaPerppu Automatic Exchange Of Information (AEOI), dirilis untuk memenuhi komitmen keikutsertaan Indonesia dalam mengimplementasikan pertukaran informasi keuangan secara otomatis. Pembentukan Perppu setingkat undang-undang mengenai akses informasi keuangan untuk kepentingan perpajakan harus diterbitkan sebelum sebelum 30 Juni 2017. Atas dasar pertimbangan tersebut dan mengingat adanya kebutuhan yang sangat mendesak untuk segera memberikan akses yang luas bagi otoritas perpajakan untuk menerima dan memperoleh informasi keuangan bagi kepentingan perpajakan, pada 8 Mei 2017, Presiden telah menandatangani Peraturan Pemerintah Pengganti Undang-Undang (Perppu) No. 1 Tahun 2017 tentang Akses Informasi Keuangan Untuk Kepentingan Perpajakan. Dari beberapa literatur termasuk muatan Perppu itu sendiri, bahwasanya Indonesia yang bila mana tidak adanya legislasi sebelum batas waktu tersebut, Indonesia akan dinyatakan sebagai fail to meet its commitment, yang membuka kemungkinan hilangnya kredibilitas sebagai anggota G-20 dan kepercayaan investor dan berpotensi terganggunya stabilitas ekonomi nasional serta menjadikan Indonesia sebagai negara tujuan penempatan dana ilegal. Pasal yang menjamin kerahasiaan data keuangan, seperti Pasal 35 dan 35A UU Ketentuan Umum dan Tata Cara Perpajakan (KUP) Nomor 6 Tahun 1983, telah dinyatakan tidak berlaku.

Lebih dari itu sebagai bentuk komitmen Indonesia secara langsung telah mengikatkan diri pada perjanjian internasional dalam bidang perpajakan dengan banyak 
negara atau yuridiksi, yang di dalamnya mengatur pertukaran informasi keuangan secara otomatis dengan standar internasional yang disepakati sebelumnya.Salah satu syarat dalam perjanjian tersebut adalah pengimplementasian peraturan/regulasi domestic terkait kebebasan akses informasi keuangan yaitu melalui Perppu Nomor 1 Tahun 2017 tentang Akses Informasi Keuangan Untuk Kepentingan Perpajakan. Berdasarkan hemat penulis dikeluarkannya perppu ini dapat menghapus keraguan atas komitmen Indonesia terhadap peningkatan transparansi sektor keuangan untuk kepentingan perpajakan. Dengan disahkannya Perppu tersebut menjadi undang-undang, maka ruang gerak bagi Wajib Pajak (WP) untuk melakukan penghindaran atau penggeseran pajak keluar dari Indonesia dapat diperangi dan diminimalkan. Dengan berpartisipasi dalam AEOI, Indonesia akan menerima secara otomatis informasi keuangan milik Wajib Pajak Indonesia yang disimpan dinegaranegara mitra AEOI, yang selama ini sulit dideteksi oleh Direktorat Jenderal Pajak. Data dari program amesti pajak terdapat sebesar 1.036 Triliun yang di deklarasikan dari luar negeri dari keseluruhan dalam dan luar negeri berjumlah 4.881 Triliun, dengan hampir 25\% total aset berada di Luar Negeri. Dengan 58,6\% dari total aset yang dideklarasikan berupa aset keuangan. Sebelum terbitnya Perppu No. 1 Tahun 2017, Direktorat Jenderal Pajak (DJP) hanya dapat memberikan pengawasan terhadap wajib pajak yang sudah melapor jumlah asetnya saja. Bahkan data aset yang didapat hanya bisa didapat melalui laporan wajib pajak sendiri. Sekarang DJP dapat memiliki informasi keuangan dari perbankan, pasar modal, perasuransian, dan lembaga jasa keuangan di dalam dan bahkan luar negeri. Mengingat bahwa 21\% dari Rp. 4.884 triliun yang dilaporkan pada tax amnesty merupakan aset yang berada di luar negeri. Akses informasi keuangan untuk kepentingan perpajakan, menurut Perppu ini, meliputi akses untuk menerima dan memperoleh informasi keuangan dalam rangka pelaksanaan ketentuan peraturan perundang-undangan di bidang perpajakan dan pelaksanaan perjanjian internasional di bidang perpajakan. Menurut Perppu ini, Direktur Jenderal Pajak (DJP) berwenang mendapatkan akses informasi keuangan untuk kepentingan perpajakan dari lembaga jasa keuangan yang melaksanakan kegiatan di sektor perbankan, pasar modal, perasuransian, lembaga jasa keuangan lainnya, dan/atau entitas 
lain yang dikategorikan sebagai lembaga keuangan sesuai standar pertukaran informasi keuangan berdasarkan perjanjian internasional di bidang perpajakan. Lembaga jasa keuangan, lembaga jasa keuangan lainnya, dan/atau entitas lain sebagaimana dimaksud, tegas Perppu ini, wajib menyampaikan kepada Direktur Jenderal Pajak:

1. laporan yang berisi informasi keuangan sesuai standar pertukaran informasi keuangan berdasarkan perjanjian internasional di bidang perpajakan untuk setiap rekening keuangan yang diidentifikasikan sebagai rekening keuangan yang wajib dilaporkan; dan

2. laporan yang berisi informasi keuangan untuk kepentingan perpajakan, yang dikelola oleh lembaga jasa keuangan, lembaga jasa keuangan lainnya, dan/atau entitas lain dimaksud selama satu tahun kalender.

Dalam Pasal 2 ayat (3) Perppu ini, berbunyi Laporan yang berisi informasi keuangan sebagaimana dimaksud, paling sedikit memuat: a. identitas pemegang rekening keuangan; b. nomor rekening keuangan; c. identitas lembaga jasa keuangan; d. saldo atau nilai rekening keuangan; dan e. penghasilan yang terkait dengan rekening keuangan. Ketika lebih lanjut Perppu ini menegaskan, lembaga jasa keuangan, lembaga jasa keuangan lainnya, dan/atau entitas lain, tidak diperbolehkan melayani: a. pembukaan rekening keuangan baru bagi nasabah baru; atau b. transaksi baru terkait rekening keuangan bagi nasabah lama, yang menolak untuk mematuhi ketentuan identifikasi rekening keuangan sebagaimana dimaksud.Dalam hal lembaga jasa keuangan, lembaga jasa keuangan lainnya, dan/atau entitas lain sebagaimana dimaksud terikat oleh kewajiban merahasiakan berdasarkan ketentuan peraturan perundang-undangan, kewajiban merahasiakan tersebut tidak berlaku dalam melaksanakan Peraturan Pemerintah Pengganti Undang-Undang ini," bunyi Pasal 2 ayat (8) Perppu ini. Menurut Perppu ini, selain menerima laporan sebagaimana dimaksud, Direktur Jenderal Pajak berwenang untuk meminta informasi dan/atau bukti atau keterangan dari lembaga jasa keuangan, lembaga jasa keuangan lainnya, dan/atau entitas lain. Informasi keuangan yang tercantum dalam laporan, dan informasi dan/atau bukti atau 
keterangan sebagaimana dimaksud, lanjut Perppu ini, digunakan sebagai basis data perpajakan Direktorat Jenderal Pajak. Kemudian berdasarkan perjanjian internasional di bidang perpajakan, Menteri Keuangan berwenang melaksanakan pertukaran informasi keuangan dan/atau informasi dan/atau bukti atau keterangan sebagaimana dimaksud dengan otoritas yang berwenang di negara atau yurisdiksi lain( bunyi Pasal 5 Perppu No. 1 Tahun 2017). Dalam melaksakan tugasnya Menteri keuangan dan/ pegawai Kementerian melaksakan tugas yang berkaitan dengan pelaksanaan akses dan pertukaran informasi keuangan untuk kepentingan perpajakan, tidak dapat dituntut secara pidana maupun diugatsecara perdata, sesuai pasal 6 ayat 1. Kemudian tidak lantas semata timbulnya Perppu Nomor 1 Tahun 2017 mengenai keterbukaan informasi keuangan ini membuat para pimpinan/pegawai tidak lepas dari ancaman pidana, perpu ini memberikan ancaman sanksi bagi pimpinan dan/atau pegawai lembaga jasa keuangan, pimpinan dan/atau pegawai lembaga jasa keuangan lainnya, dan pimpinan dan/atau pegawai entitas yang: a. tidak menyampaikan laporan sebagaimana dimaksud; b. tidak melaksanakan prosedur identifikasi rekening keuangan secara benar; dan/atau c. tidak memberikan informasi dan/atau bukti atau keterangan sebagaimana dimaksud dipidana dengan pidana kurungan paling lama 1 (satu) tahun atau denda paling banyak Rp1.000.000.000,00 (satu miliar rupiah). Sedangkan kepada lembaga jasa keuangan, lembaga jasa keuangan lainnya, dan/atau entitas lain yang: a. tidak menyampaikan laporan sebagaimana dimaksud; b. tidak melaksanakan prosedur identifikasi rekening keuangan secara benar; dan/atau c. tidak memberikan informasi dan/atau bukti atau keterangan dipidana denda paling banyak Rp1.000.000.000,00 (satu miliar rupiah). Setiap orang yang membuat pernyataan palsu atau menyembunyikan atau mengurangkan informasi yang sebenarnya dari informasi yang wajib disampaikan dalam laporan sebagaimana dimaksud, menurut Perppu ini, dipidana dengan pidana kurungan paling lama 1 (satu) tahun atau denda paling banyak Rp1.000.000.000,00 (satu miliar rupiah).

\section{B. Kebutuhan dan Urgensi}


Telah disinggug sebelumnya bahwa pembangunan segala aspek negara sebagian besar ditopang oleh pendapatan yang berasal dari komponen pungutan pajak.Terdapat kendala baik dalam tataran internal maupun ekternal dalam proses penerimaan pajak. Kendala internal yang dimaksud adalah masih berjalannya proses reformasi perpajakan pada Derektorat Jendral Pajak, tujuannya antara lain menata dan memperbaiki organisasi, proses kerja, pengelolaan data dan informasi yang berasal dari perbankan, serta menata dan meningkatkan sumber daya manusia (SDM). Faktor eksternal yang mengharuskan adanya keterbukaan informasi seperti yang disinggung sebelumnya adalah telah terjadinya pelamahan ekonomi dan perdagangan global serta massif dan banyaknya ditemukan wajib pajak (WP) yang melakukan tindakan penghindaran pajak keluar Indonesia. Dengan adanya pelarian pajak atau pembebasan (tax heaven) makin memperkeruh pengumpulan pajak Indonesia secara self-assessment ketika belum terdapatnya pertukaran informasi yang akurat dan yuridiksi. Pengawasan wajib pajak melalui system self-assessment pada dasarnya merupakan salah satu cara terbaik dalam upaya menertibkan penerimaan pajak. Hal tersebut akan dapat terpenuhi jika terpenuhinya basis data yang kuat, akurat dan cepat, serta akses yang luas bagi otoritas perpajakan guna menerima dan memperoleh berbagai informasi keuangan bagi kepentingan perpajakan. Berdasarkan fakta yang terjadi di lapangan ketentuan peraturan perundang-undangan khususnya bidang perpajakan, perbankan, dan pasar modal serta peraturan perundang-undangan yang berlaku saat ini masih sangat membatasi akses otoritas perpajakan dari segi prosedur dan persyaratan kaitannya dalam mendapatkan informasi keuangan.Kondisi tersebut sangat dimanfatkan oleh masyarakat "wajib pajak (WP) untuk tidak melaporkan penghasilan maupun harta sebenarnya. Dampak berkepanjangan dari hal tersebut yaitu menghambat kebijakan terkait pengampunan pajak dan yang paling parah adalah Indonesia dapat dijadikan penempatan dana illegal. Saat ini Global Forum on Transparency and Excange of Informationfor tax Purposes (Global Forum) telah memiliki anggota sebanyak 139 yuridiksi atau negara, termasuk Indonesia, telah melakukan transparansi dan pertukaran informasi yang efektiv bagi tiap-tiap negara. Posisi Indonesia saat ini berstatus sebagai negara dengan peringkat 
"Patuh Sebagian" karena ketiadaan Kewenangan Derektorat Jendral Pajak untuk memperoleh informasi secara total terhadap perpajakan, perbankan, perbankan syariah, dan pasar modal. Status dengan "Patuh Sebagian" dimaksud mengakibatkan Indonesia dianggap tidak transparan dalam pertukaran arus informasi keuangan oleh anggota negara/yuridiksi di forum internasional. Berkaitan dengan hal tesebut ketika Indonesia tidak mengeluarkan Perppu No.1 Tahun 2107 Tentang Akses Informasi Keuangan Untuk Kepentingan Perpajakan, maka dapat dipastikan dalam Global Forum memberikan peringkat terhadap Indonesia sebagai negara beresiko gagal (ar risk) memenuhi komitmen AEOI. Artinya dalam hal ini Indonesia dipublikasikan sebagai negara yang gagal dalam mewujudkan komitmen AEOI yang secara otomatis Indonesia akan termasuk dalam satuan negara yang tidak kooperatif. Hal tersebut akan memberikan dampak kerugian yang sangat drastic seperti menurunnya kepercayaan investor, guncangnya stabilitas ekonomi nasional, dan dapat dipastikan Indonesia akan menjadi sasaran penempatan dana illegal.

\section{KESIMPULAN}

Sebagai konsekuensi keterikatan Indoneia sebagai anggota G-20 serta ikut menandatangani Multilateral Competent Authotity Agreement yang mencantumkan komitmen Indonesia untuk memulai AEOI, yang otomatis harus mengambil sikap cepat tanggap terhadap peraturan yang telah disepakati secara Internasional. Perpu mempunyai kesederajatan dengan Undang-undang, karena materi muatannya semestinya diatur dengan undang-undang, namun karena suatu kegentingan yang memaksa. Pemahaman mengenai hal "ikhwal kegentingan yang memaksa" diartikan juga dengan "kepentingan yang mendesak dengan kritria sebagai berikut berdasar keputusan MK No. 138/PUU-VII/2009, dalam tiga hal :

1) Adanya kebutuhan mendesak untuk menyelesaikan masalah hukum secara cepat berdasarkan UU,

2) UU yang dibutuhkan tersebut belum ada (Kekosongan hukum) atau ada undangundang tapi tidak memadai, dan 
3) Kekosongan hukum tersebut tidak dapat diatasi dengan membuat undangundang secara prosedir bisa karena membutuhkan waktu yang lama.

Sama seperti pendapat Jimly Asshiddiqie, 3 hal diakatakan kegentingan memaksa adalah ancaman yang membahayakan, kebutuhan yang mengharuskan, dan keterbatasan waktu. Dimana penulis menilaindakan pemerintah atas respon penebitan Perppu Nomor 1 Tahun 2017 sudah tepat dan memenuhi ketiga unsur diatas. Penulis berkesimpulan memang seharusnya terbitnya Perppu sebagai sikap komitmen Indonesia terhadap peningkatan transparansi sektor keuangan untuk kepentingan perpajakan. Diharapkan dengan disahkannya Perppu tersebut menjadi undangundang, maka ruang gerak bagi Wajib Pajak (WP) untuk melakukan penghindaran atau penggeseran pajak keluar dari Indonesia dapat diperangi dan diminimalkan. Dengan berpartisipasi dalam AEOI, Indonesia akan menerima secara otomatis informasi keuangan milik Wajib Pajak Indonesia yang disimpan di negara-negara mitra AEOI, yang selama ini sulit dideteksi oleh Direktorat Jenderal Pajak. Implikasi tersebut mengakibatkan lambatnya pembangunan nasional serta rendahnya power pemerintah dalam mensejahterakan rakyat yang merupakan fungsi dari pajak itu sendiri.

\section{DAFTAR PUSTAKA:}

Bagir Manan. 1992. Dasar-dasar Perundang-Undangan Indonesia. Ind-Hill.Co. Jakarta Hlm 18.

Donal O.Case. 2007. Looking for Information : A survey of Research on Information Seeking, Needs, and Behavior. (London: Academic Press, hal 42).

Hidayat, A. (2017). Budaya Kerja, Kepuasan Kerja Dan Kinerja Pegawai Pt. Trijaya Medika Farma: Motivasi Sebagai Moderator. Sains: Jurnal Manajemen Dan Bisnis, 10(1), 377389. https://doi.org/10.35448/jmb.v10i1.4274

Kementerian Komunikasi dan Informatika RI, Peraturan Menteri Komunikasi dan 
Informatika Nomor 10 Tahun 2010, Tentang Pedoman Pengelolaan Informasi dan Dokumentasi Di Lingkungan Kementerian Komunikasi dan Informatika (Jakarta:Kementerian Komunikasi dan Indormatika RI, 2010), 5.

Maria Farida. 2006. Ilmu Perundang-undangan, Dasar-dasar dan Pembantukkannya. Kansinus.Yogyakarta.HIm 3.

Zed, M. 2014.Metode Penelitian Kepustakaan . Jakarta: Yayasan Obor Indonesia. https://nasional.kompas.com/read/2017/02/28/18463821/jokowi.terbitkan.perppu.terka it.keterbukaan.informasi.keuangan.pada.juli.2017 (Diakses pada 26 November 2018, Pukul 00:32)

https://www.kompasiana.com/farhanrahadian/5a3a933acaf7db43e4441602/tujuanperubahan-dan-pembahasan-perppu-no-1-tahun-2017-tentang-aksesinformasi-keuangan-untuk-kepentingan-perpajakkan

http://mediaindonesia.com/read/detail/114885-perppu-akses-informasi-keuanganuntuk-kepentingan-perpajakan-disahkan-jadi-uu http://setkab.go.id/perppu-no-12017-petugas-pajak-berwenang-peroleh-aksesinformasi-perpajakan-dari-lembaga-jasa-keuangan/ 